\title{
Biblical Reflections in
}

\section{the Arabic Lexicon}

\author{
AVery Modern Translation Phenomenon \\ The 1857 translation of the bible left the indelible impress of \\ American missionaries on modern Arabic. \\ This translation was a dialogic success \\ in a process that intended (but partially failed) \\ to enforce a synchronization of Arab society \\ By Rana Issa, a Kultrans Doctoral Fellow \\ along Protestant Western lines. \\ at the Centre of Islam at Middle Eastern \\ Studies, University of Oslo.
}

FIFTEEN YEARS AFTER the rejection of his application to become pastor of the first Arab Protestant church, Butrus al-Bustani parted with American evangelists. Between the native Church he helped found in 1848 , and his lonely establishment of the first nondenominational school in the Ottoman Empire in I863, Bustani worked, under American missionary supervision, on the translation of a bible whose name in American scholarship is the Smith-Van Dyck bible. ${ }^{\text {I For }}$ Arabs, this translation is the Bustani-Van Dyck bible. If Americans forget to mention the name of one of the most important architects of Arab literary modernity, with a career that begins with the bible and extends to lexicons, an encyclopedia, important newspapers and famed literary salons, the Arabs fail to recollect an American whose most memorable work is the translation of the bible. ${ }^{2}$
If a book's title carries its differential mark, then the elisions in the titles of this bible carry the singularity of the American-Arabic bible translation of I863. In the instability of the titles, the bible, as this paper argues, emerges as a site that mediates the relationship between American missionaries and the Arab natives of Syria in late Ottoman Lebanon. Forgetful of Eli Smith, Arabs vindicate Bustani's struggle against the missionary who continuously rejected the appointment of a native pastor for the first native Evangelical Church. For Americans who accepted the ordination of a native pastor only in 1890 , their failure to recollect Bustani's role in the translation exposes their blindness to native agency. Despite the forgetfulness of dialectical power struggles carried silently in its titles, I believe that the Smith-Bustani-Van Dyck (SBV) Bible is a transnational product that dialogically mediated 
the relationship between the three principle translators, namely Smith, Cornelius Van Dyck and Bustani.

In the branch of biblical scholarship associated with the work of Eugene Nida, there is nothing radical in observing the Bbible's ontological dialogism; indeed, the pragmatics of the encounter between missionaries and native partners continues to influence the publishing of several hundreds of translations of the bible in the world. However, my readings from Middle Eastern history and postcolonial studies, American missionary history as well as modern Arabic philology and translation, have a different, more sociological concern that analyzes the bible through the politics of its reception. In postcolonial studies, the focus has traditionally been on the devastating impact of bible translations on indigenous populations, such as in the seminal work on Maori literacy by Donald McKenzie, ${ }^{3}$ where translating Bbibles is contextualized within a larger historical process of colonization described as a disastrous relationship between the West and the Rest. In contrast, this paper heeds Ussama Makdisi's description of the colonial encounter as a general rule of native Arab collaboration with the West, where the emphasis on native agency is examined more thoroughly. ${ }^{4}$ I find Heather Sharkey's sociolinguistic examination of Sudanese bible translations exemplary in surpassing a postcolonial problematic, where her research is closely related to my views on how native agents voiced strong expectations and ultimately shaped the reception of Sudanese dialect bibles. ${ }^{5}$ Hikmat Kachouh's prodigious work provided me with the background for the philological observations I make in this article. ${ }^{6}$ My philological approach to the SBV 
bible was inspired by Oddbjørn Leirvik's arguments about how SBV contributed to expanding the semantic field of key Arabic concepts.? The History of the Book in America contains several articles about missionary publishing practices that were invaluable in emphasizing the materiality of bible publishing as a methodological example of literary history about missionary institutions in the United States. ${ }^{8}$ By opening my research on two geographical areas informed by transdisciplinary approaches, I define the bible as a foundational, transnational text, where my examination of SBV intends to locate the impress of the peculiarly modern beginnings of American engagement in the Middle East.

My investigation of the most popular Arabic bible in use today attempts to examine the consequences of this transnational encounter on shaping this translation. I employ Laura Doyle's transnational definition, to emphasize the global connections between institutions, peoples and histories that shaped the production of the bible. The entanglements of "the odd, uneven time-travel of world-system economies and the lived placedness of human lives" ${ }^{\prime \prime}$ sustain my reflection on the dialectical (de)formations that framed the SBV bible. By suggesting that the bible was a dialogic instance of American-Arab contact, I borrow from Mikhail Bakhtin's $\mathrm{s}^{10}$ theories of how authority is mediated, and sometimes even resisted, through textual practices. I contend that without re-presenting the bible translation through its dialogical manifestations, one cannot understand the enormous impact of transnational connections on (de)forming the function of the bible as it shaped a modern Arabic lexicon.

I ask how translation as a transnational literary activity mediated the ideological con- flicts and synchronizations in the relationship of Americans to key Arab intellectuals. By focusing on the cultural implications of technical translational decisions, I argue that the Americans contributed to a translation of the bible that became a siginificant Arab textual monument.

\section{The decision to translate the bible}

For American evangelists, spreading the Gospel was their noblest path to self-redemption. Motivated by feelings of individual responsibility in ushering in the End Time, ${ }^{\text {II }}$ American missionaries measured their success by counting the number of bible pages that they printed and distributed.

When in $186 \circ$, parts of the NT were published in Beirut in the midst of a civil war, the American Board of Commissioners for Foreign Missions (ABCFM) $)^{12}$ referred in its annual report to the massacres of Christians as a timely opportunity for the spreading of the Gospel. Recollecting the war through the lens of the translation, they wrote, "It was a remarkable and providential fact that just at the time when the massacres of 1860 in Syria had driven many thousand refugees into Beirut, the new translation of the New Testament was ready to be distributed and sold to them. ${ }^{{ }^{13}}$ Their callousness to suffering, justified by the millennial End, the missionaries were being sincere to their faith by suggesting that the souls of Eastern Christians were only worth saving if reconciled with the Word (of the SBV bible).

Americans were not the first Protestants to venture a translation of the bible into Arabic. British missionaries before them set an example of "benevolence" to "heathen and uncivilized natives" by publishing an Arabic translation of the bible in I8II, completed by Rev. J.D 
Carlyle and financed in advance through subscriptions by Asian and African stations. ${ }^{14}$ Prior to this translation, no known Protestant translation of the bible to Arabic existed. British missionaries often relied on Rome's I671 Biblica Sacra Arabica ${ }^{15}$ that was reprinted in London by missionary presses. ${ }^{16}$ They also

$$
\odot \odot \odot
$$

\section{Americans were not the first \\ Protestants to venture a translation of the bible into Arabic.}

$\odot \odot \odot$

relied on a selective translation attempted in India by Anglicans some decades earlier. Clumsy printing and linguistic weaknesses marred these translations that Americans imported from England.

As they became more intimately acquainted with Arab culture, they were confronted with the faults of English Bbibles. According to their research, the bible existed in Arabic as far back as the 8 th century, ${ }^{17}$ a fact that historically intertwined the bible in the language of Arabs. In order to adequately compete in this rich textual landscape, they deemed it necessary to supply the Arabs with a bible that rivalled the Quran's holiness as well as supersede the diverse bibles of the Eastern Churches. This reality induced a reformulation of the original methods that the missionaries had planned. Their first concession was the choice of source text from which to translate. After arriving in the Levant, the missionaries abandoned their initial plan to translate the bible from the King James Authorized Version (KJV). Commenting on the Turko-Armenian translation, Jonas King wrote on August 3I, I830, ${ }^{18}$ "Most of the translations must obvi- ously be made from the English tongue, and there are very few persons, born in the Levant, who have a competent acquaintance with that language." ${ }^{19}$ A year later, William Goodell and Bishop Dionysius published an Armeno-Turkish NT and declared it translated from the “original Greek". ${ }^{2 \circ}$

Based on the nature of the audience, the KJV's relative newness could not have adequately performed as a source text. The Levant was the birthplace of the bible and its readers were well versed in all its ancient languages and a number of modern ones. Whereas the missionaries were not conversant in any modern tongue on arrival in the Mediterranean, the polyphony of languages in the region confounded missionary proselytizing labour. Relaying the linguistic hardships of missionary work, ABCFM foreign secretary Rufus Anderson wrote:

"The Maronite Syrians spoke the Arabic language, but employed Syriac alphabet in writing. The Armenians, to a large extent, spoke the Turkish language, but used Greek alphabet. The Greeks in Asia generally spoke the Turkish language, but used the Greek alphabet. The Grecian Jews spoke the Grecian language, the Spanish Jews the Spanish, the Barbary Jews the Arabic, but all three used the Hebrew alphabet. Then too, the worship of the Syrians, Greeks, and Armenians was in the ancient languages of those nations, which were in the most part unintelligible for the common people (p. 75).”

Such heteroglossic communities whose Bbibles were still read in ancient tongues and who have been translating into Arabic earlier than the 8th century coexisted for centuries with the "miracle" of the Quran. The KJV had no place in such landscape. 
By abandoning their plans to translate from the King James Bible, the American missionaries had become pioneers within the Third world of Anglophone Protestantism. The Bbibles that were published in Modern Greek, Armenian, Arabic and Italian were all translated from ancient tongues and not from the KJV. The Maltese bible was the only exception, and this was perhaps because Maltese, until that moment in history, was an oral language: a bastard of Arabic that the Arabs did not count among their dialects, coloured with pidgin Italian that Italians hardly understood. First reducing Maltese to script by writing an English-Maltese lexicon and grammar, the Americans translated the Maltese bible from $\mathrm{KJV}$, following closely the example of British missionaries stationed among oral tribes. ${ }^{21}$

Their course corrected by the cultural reality of the Middle East, the Americans invented new guidelines for their translation activity. Luckily for them, Smith was a dedicated scholar who acquired admirable fluency in Arabic fairly quickly. As Isaac Hall writes, without the persistent vision of Smith, this edition would not have materialized. Hall credits him with being "the first to assert... that a new translation of the bible was indispensable" (p. 283). After his proposal was approved, Smith began compiling an impressive reference library. He also personally trained Bustani in Hebrew and Greek. Before his death in January I857, Smith had finished the translation of the Gospels, and large sections of the OT, although as he warned his successor Van Dyck, he was only responsible for it from Genesis until the third chapter of Exodus.

The choice of Van Dyck as a successor was natural. Not only was he a member of the peer review board of Smith's work, but he was also the most fluent Arabic speaker, boasting a number of Arabic publications, in geography, medicine, astrology and logic. The solid friendship he fostered with Bustani and his intimate ties with leaders of various denominations would later become central to the acceptance of the SBV by the Orthodox Church. As Makdisi describes him, Van Dyck was the only liberal missionary to have worked for the Syria mission. After breaking ranks with the missionaries following a crisis over Darwinism in the medical school of the Syrian Protestant College, the aged Van Dyck assisted the Greek Orthodox community in building a medical centre as well as a school. Perhaps in gratitude for his efforts, the SBV was accepted as the official bible text of the Greek Orthodox community, the largest Christian sect in the Levant.

\section{Original bible source(s)?}

According to Smith and Van Dyck, ${ }^{22}$ ABCFM instructed the translators to use the Textus Receptus as the authentic, original Greek text. This text was edited and collated by Erasmus in the I5th century, and was the basis for the KJV. Smith who was well acquainted with the field of critical bible studies emerging in Protestant circles, discarded the more conservative views of his superiors. When Van Dyck took over, he discovered that the New Testament translation did not follow the Textus Receptus and that "this the Bible Society could not allow." ${ }_{23}$ For the ABCFM, any deviation from John Mill's edition of the Textus Receptus was to be burned or destroyed "as if useless." ${ }^{24}$ Moreover, Smith, from the outset, drew the Peshitta into his reference collection, an important Syriac bible text, as another original lexical source in his translation, further interlocking this modern translation of the bible with a style familiar to the Eastern Churches, 
in this case especially the Syriac vocabulary of the Maronite Church.

Smith's reference library inherited by the Near East School of Theology (NEST) in Beirut, shows that Smith and Van Dyck built their translation on existing Arabic texts purchased from monasteries in Syria, Iraq and Egypt. Their contribution to this rich Arabic bible tradition benefited from their settlement in Beirut. It positioned their translation at the nexus of historical and transnational bible currents that augmented the manuscriptbased market of pre-modernity. Hikmat Kachouh's recent classification of several hundreds of pre-Igth century Gospel manuscripts into 26 families shows that the largest of the manuscript families (his so-called Beiruti bibles) came from the Levant. While his work shows that Mount Lebanon was already a centre of academic Christianity for the various Eastern Churches in the pre-modern Christian world, it suggests as well that an unhampered intertextuality existed between the different churches, where some of these Bbibles were copied and adapted, and even borrowed from each other. By building on Kachouh's findings, I will demonstrate in what follows that the main transformation triggered by Protestant translations and printing practices can be analysed through a question of intertextuality, or to phrase it differently, the extent to which various Eastern Churches eventually ceased to read and adopt sections of each other's bible texts. ${ }^{25}$

The originality of American intervention can be stated quoting Smith, "For the different parts of the Arabic Bible most in use have been taken by translations made by different hands, and there is great want of uniformity in the phraseology used" (p. 8). Earlier, he mentioned that "the structure of the sentences is awkward, the choice of words not select, and the rules of grammar are often transgressed. We have been ashamed to put the sacred books of our religion, in such a dress, into the hands of a respectable Muhammedan or Druze and felt it our duty to accompany them with an apology" (pp. I-2). To redress these problems, Smith hired Bustani, who acquired Syriac in the elite Maronite seminary of Ayn Waraqa.

Working closely with such erudite scholars as Smith and Van Dyck, Bustani became deeply acquainted with the Western philological tradition, especially the branch connected with developments in biblical studies. In his

$$
\odot \odot \odot
$$

One problem facing missionary printers was the complexity of Arabic fonts.

$\odot \odot \odot$

lexical work two decades later, Bustani introduced to the Arabic language a number of words that originate in Christian settings, both of Arabic and foreign origins, but that have never made it into the authoritative Arabic lexicons. Such words are ilmaniyyah (secularism) and namus, which comes from the Greek/Syriac (nomos) and which the SBV preferred over shar'ah, sunna, or even tawrat (Torah). ${ }^{26}$ Bustani's lexicon also includes pioneering definitions of masih (Christ) and masihi (Christian), 'mmada (baptize) of Arabic origin, while tilmid (disciple, student) are of Hebrew/Syriac origin. These words exist in prior lexicons without mention of their meaning within Christianity. Tilmid, which now commonly has the secular meaning of student, was also first entered into the Arabic lex- 
icon in this modern educational sense by Bustani.

This is a good occasion to mention the widely held belief among historians of Arabic that the translation of the bible "contributed to the modernization of the Arabic language" 27 (p. I93). From a linguistic perspective, the language of the bible was not designed to break with Arabic grammar. Actually, Smith favoured a Quranic turn of phrase. To ensure that the translation was palatable to Muslims, Van Dyck employed the Azhari sheikh Yusuf Al-Asir as copy editor; he vowelled the entire manuscript while combing through for chance "foreign idiom". ${ }^{28}$ Thus it was not American missionaries who would have suggested the use of namus instead of shari'ah but as Van Dyck clearly pointed out, "all native Christian scholars decidedly objected" to the adoption of "idioms and expressions peculiar to Muhammedans" (p. 28). ${ }^{29}$ Van Dyck accepted this argument and revised all the proofs that had been drafted, to ensure that "a simple but pure Arabic, free from foreign [sic] idioms" was to be adopted. As Smith stipulated, by adhering to the rules of classical Arabic,

"we are able to avoid, in a great degree, giving the work the savor of a local dialect, which would be impossible were we to descend to the vulgar language of conversation. We also bear in mind that the work is designed for a race, only a small portion of which are Christians; and consequently are on our guard in reference to the many words which are current among Christians, in a meaning not sanctioned by Mohammedan usage, lest by using them we convey a wrong idea to a Mohammedan mind (p. 10)."

What then was the immediate impact of the bible translation on Arab literary life? And in what way did it "modernize" the language as is often claimed? One can find partial answers to these questions by examining how the translation of the bible also contributed to Arabic printing.

One problem facing missionary printers was the complexity of Arabic fonts that confounded their peers prior to the SBV edition. Arabic's cursive script stipulated that each letter took four shapes, compounded by the problem of short vowels. What resulted were fonts of 600 and I,200 characters, each page set individually with pincers, by typesetters

$$
\odot \odot \odot
$$

The Jesuit translation succeeded in superseding the Protestant translation among its constituency.

$$
\odot \odot \odot
$$

versed in Arabic. Moreover, Arabs and Muslims were sceptical of print technology, and while printing of Christian literature was tolerated and flourished in monasteries of Eastern Churches, the highly developed style of Muslim calligraphy and the precision of Islamic copying practices dominated the production of Arabic texts, whatever the religion. Working with the punchcutter Homan Hallock, Smith gathered samples from various famed calligraphers. Hallock used them as the basis for his matrices. Smith travelled with the designs to Leipzig where Tauchnitz, a missionary sympathizer acquainted with Oriental script, cut it. ${ }^{30}$ This new font was later labelled "American font" and gained, for some time, a wide circulation amongst Levantine printing presses. After publishing the bible in this font, Van Dyck proudly exclaimed that "Those who are aware of the fact that, but a few years since, this people could with difficulty be 
induced to accept the Bible gratis, will be able to duly appreciate this fact, that so many copies have been sold within so short a period". ${ }^{31}$ In the same report, Henry Jessup also rejoiced that

"the whole Mohammedan world can read the New Testament of the Bible. They constantly objected to the old translation as not being the word of God, because it was not correct Arabic, and the Arabic is a sacred language. A Mohammedan in Sidon on seeing the vowelled edition of the New Testament gave out word that the lost Enjeel... was found. " ${ }^{2}$

These exaggerated jubilations were intended to obscure to American donors - whose financial support guaranteed technological upgrades at the press - the complicated reception of the SBV, especially among the local Churches.

By I864, 6,000 copies of the SBV had been distributed, which was a major turning point in the history of the dissemination of copies of the bible copies. Threatened by the modern dress of the Protestant bible, the Maronites entreated their superiors in the Levant and in Rome to authorize a new Catholic translation of Scriptures. Published almost a decade later, in $1877,,^{33}$ and translated by the famous intellectual Ibrahim al-Yaziji together with the Jesuit Van Ham and the head of the Jesuit order Ambrosios Monnot, this bible frankly stated why a new version of a Catholic bible had become indispensable. In the introduction to the first edition of this bible, the Protestants were identified as wrote this translation hoped to exorcise. They write:

"It is obvious that a group of inventors from the Protestant sect, since they entered the lands of
Syria, were concentrating through their actions on undermining the Catholic faith. In every town they visited, they fabricated in religion, with various books that they infused with slander...They were not satisfied with this until their hands tampered with the sacred books with distortions and omissions which they translated and published in the Arabic tongue... and they decorated it in the eyes of people through superior printing and the beauty of form. They also made it cheap to induce the people of peace to accept it and desire it...This is why the leaders of the Holy See in the East were sorry because they knew what this path holds for the perishing souls and they entreated several times the General head of the Jesuit Message in these regions to expend his attention to the translation of the Glorious Book in Arabic from its perfect and sound original so that the believers are protected from the traps of the heretics and their corruption."

Eager to dispel the belief that they deliberately maintain their adherents in ignorance, the Jesuits printed a truly beautiful book, adorned with an exquisite Istanbuli font, with a design teaming with intricate punctuations and frames unique for every page, four-colour printing and gold leaf on the edges, superior leather binding, in three octavo volumes beginning each with the authorizing seal of Rome. When in the introduction they mentioned that they translated from the original, Van Ham writes that they meant "Latin, Syriac, and Septuagint, whereas if there was a discrepancy in some verses that are about faith or morals, the Latin copy was depended upon as a constitution to return to absolutely because it is the one authorized by God's selection since an ancient time and it was fixed by the Council of Trent" (p. 6).

In the Jesuit translation, the whole notion 
of the "original" becomes contentious. Waving the authorized ancient texts that were part of the Maronite/Catholic textual canon, these "original" sources reinstated the Vatican's biblical tradition as the "authentic" rival of the American bible. Intertwining authenticity with the decrees of the Council of Trent deliberately positioned the Jesuit bible in communion with the Counter-Reformation and introduced to the Eastern Church a conflict that started four centuries earlier on the European continent. Upon its publication, the Jesuit translation succeeded in superseding the Protestant translation among its constituency. However, with two competing bibles published in the same city, a new era of language politics in the Arab world emerged, where an entire glossary of distinctly Christian terms and concepts entered into the lexicon of the Arabic language. The rivalry over ownership of the bible contributed to this lexical endorsement of Christianity. While in pre-modern days the bible was shared and copied across the sects and churches, in the wake of the large dissemination of the SBV, the bible transformed into a prized commodity indeed a site - for sectarian rivalry in Lebanon. The introduction of the Jesuit bible symptomatically grappled with this transformed reality. Paradoxically, the publication of these competing texts forged an unquestionable place for the bible in the canon of Arabic letters, where its identity as a holy text rendered it dialectically significant, and thus ensured its influence on the lexicon.

Through Bustani's monumental contribution to Arabic lexicography, the bible was reinvented as a pillar of Arab culture, standing with Abbasid poets and Quranic discourses. His status as a foundational modernizer of the Arabic language rested upon his success in making the bible linguistically impressive to a reading public that is not only Christian (and might not even be reading the bible). By turning the bible into a pillar of Arab modernity, Bustani opened up a dialectical engagement with Arabic that subverted its divine economy for Muslims as well as challenged it to reinvent the relations between a Muslim majority and a minor (and historically continuous) Christian presence. To rival Bustani's lexical prowess, the 13th century lexicon Lisan al'arab by Ibn Mandur was printed in 1883 . However, Bustani's Muhit became the paradigmatic lexicon of the new period. If language is the mirror of the nation, as Bustani was fond of repeating, then his achievement could be described as the invention of an Arab/Christian, Syrian/Beiruti "nation" by giving it a bible as its originating Scripture and inventing for it a new dialect based on religious difference. Since then, this dialect has been widely known as Christian Arabic.

$$
\cdot f \cdot
$$

I I write the bible with a small b so that I can heighten awareness toits materiality, which is what I am writing about. I speak of the bible as an entire library of texts and not what most people would mean when they say Bible.

2 Exceptions to this claim are Issa Saliba, who prefers to use Smith-Van Dyck and from a Western, Protestant perspective and Oddbjørn Leirvik, who uses BustaniVan Dyck. References below. However, as a general rule, one of the two titles is usually employed.

3 McKenzie, Donald:. "The Sociology of a Text: Orality, Literacy and Print in Early New Zealand." The Library. VI, No. 4, December I984. Pp333-65.

4 Makdisi, Ussama:. Cultures of Sectarianism Community, History, and Violence in Nineteenth-Century Ottoman Lebanon. Los Angeles: University of California, 2000.

5 Sharkey, Heather:. "Sudanese Arabic Bibles and the Politics of Translation." Bible Translation.62:I, pp37-45. For earlier work see Somekh, Sasson "Arabic Bibles in the Modern Age: Linguistic and Stylistic Issues." Professorship of Semitic Languages. Jubilee Volume. Upp 
sala: Uppsala University, 2007. Thompson, John A.: "The Origin and Nature of the Chief Printed Arabic Bibles" Bible Translator, I955. Pp98- I49. Issa Saliba "The Bible in Arabic: The I9th century Protestant Translation." The Muslim World. MW65 (I975) pp25363.

6 Kachouh, Hikmat: Arab Versions of the Gospels: The Manuscripts and their Families. Berlin: de Greuyter, $2 \mathrm{OI} 2$.

7 Leirvik, Oddbjørn: "Conscience in Arabic and the Semantic History of Damir." Journal of Arabic and Islamic Studies. 9:2, 2009. ppi8-36.

8 Hall, David: (et al ed.) History of the Book in America. 5 Vols. Cambridge: Cambridge University Press, 2000.

9 Doyle, Laura: "Toward a Philosophy of Transnationalism." Journal of Transnational American Studies I:I, (2009). Jstor. Ppi-29.

Io Bakhtin, Mikhail. The Dialogic Imagination: Four Essays. ed. Michael Holquist. trans. Caryl Emerson and Michael Holquist. Austin: University of Texas, I98I.

II For more on the American missionary millennial ideology, see Hutchison, William R. Errand to the World: American Protestant Thought and Foreign Missions. Chicago: University of Chicago Press, I987.

I2 ABCFM was established in Boston in I8Io. Its Levantine mission set out to Jerusalem in I8Ig. For history of the contact with Arabs See Makdisi. Cultures. For its reception at home see Shenk, Wilbert R.: ed. North American Foreign Missions, 1810-1914. Cambridge: Ww. B. Eerdmans, 2004 .

I3 Annual Report of the American Bible Society. vol 4 New York: American Bible Society, I87i. P.I29. Google ebooks. Last accessed: 29.05.20I2.

I4 This bible is known by the name of its printer John Watts.

I5 This edition was translated by the Maronite bishop of Damascus Sarkis el-Rus (Sergius Risius) and edited by Lodovico Marracci et al.

I6 See Smith, Eli and Van Dyck, Cornelius: et al. Brief Documentary History of the Translations of the Scriptures into the Arabic Language. Beirut: Syria Mission, I900. P. I

I7 See Pollock, James W: Catalogue of Manuscripts of the Library of the Near East School of Theology. In Theological Review. I:4. Beirut: Near East School of Theology, I98I. Issac H. Hall, Issac H.: "The Arabic Bible of Drs. Eli Smith and Cornelius V.A. Van Dyck." Journal of the American Oriental Society. Vol II (I885), pp 276-86. Recent scholarship suggests an even earlier existence of the Arabic bible. See Arbache, Samir: "Bible et liturgie chez le Arabes chretiens (Vie-Ixe siecle)". Ed Thomas, David. The Bible in Arab Christianity. Leiden: Brill, 2007. Also see Kachouh's discussion on Family H.

I8 Salibi, Kamal and Khuri, Yusuf Kuzma: eds. Missionary
Herald: Reports from Ottoman Syria 1818-1870. Amman: The Royal Institute of Interfaith Studies, I995.

I9 Ibid. Vol 2, p. 279 or Missionary Herald, year I83I, vol 27. P. 42.

20 Ibid, published on Jan 23, I8 32 .

2I See McKenzie's discussion of Maori bibles for a history of missionary practices working with oral languages.

22 See Brief Documentary.

23 Hall, p.p 279.

24 Ibid., p. 282. There has been some suggestions that all Smith's earlier drafts have been burned, a hypothesis largely based on the fact that these drafts are the only ones not included in NEST's holdings.

25 See for example Kachouh's description of the position of the Alexandrian Vulgate through a diverse set of bibles from different churches. Or his quotation from Louis Chiekho referring to a Greek Orthodox manuscript which is a copy of a Roman text (p. I73).

26 See Bustani, Butrus. Muhit al-Muhit entries for these words.

27 Kassir, Samir is the most recent historian who claims for this translation a pivotal role in the life of modern Arabic. See Tarih Beirut. (Histoire de Beyrouth). Trans. Mary Tawq Ghosh. Beirut: Annahār, 2006 (p. I93).

28 Brief Documentary, p. 23.

29 The discussion amongst Christian Arabs continues on how key terms must be translated in Arabic bibles. See Samir S. K, Khalil (2005). "Nahu Mustalahat Masihiyyah 'arabiyyah Mu'asirah Muwahhadah (Towards a Unified Christian Arabic Termonology)”). Gazir, Mansurat Ikriliyyah al-Batriyarkiyah al-Maruniyah: p. II-I8.

30 For a full account on the development of the so-called American font and the punchcutting labor of Homan Hallock, see the article by J.F. Coakley "Homan Hallock, Punchcutter." Printing History. Vol 23 I(45), 2003.

3I Annual Report of the American Bible Society. vol 4. New York: American Bible Society, i87i. Googlebooks. Last accessed: 29.05.2012. P. I30.

32 Ibid, p. I29.

33 "Introduction" to the Holy Bible. Beirut: Jesuit Press, I877. 